\title{
Notes on the conservation status of resident diurnal raptors of the middle Cauca Valley, Colombia
}

\author{
HUMBERTO ALVAREZ-LOPEZ and GUSTAVO H. KATTAN
}

\begin{abstract}
Summary
Historical and anecdotal data indicate that out of 14 original species of resident diurnal raptors, six have become extinct and two more are considered endangered in the middle Cauca Valley, Colombia. While the decline of several species is related to a drastic reduction of original habitats such as forests and wetlands, three open-habitat species have also suffered population declines. Possible causes include the recent expansion of intensive agriculture (at the expense of cattle-ranching areas), agrochemical pollution, hunting, and factors such as body size, the proximity of the valley to the upper altitudinal limit of most of the affected species, and the relative isolation of the valley from the Caribbean region and the savannas east of the Andes. The need for monitoring projects is stressed for the vertebrate fauna, including those species considered common in open and disturbed habitats.
\end{abstract}

Informaciones históricas y anecdóticas indican que de una fauna original de 14 especies de aves rapaces diurnas residentes en el valle medio del río Cauca, Colombia, se han extinguido seis especies $y$ dos más se consideran amenazadas. Mientras que la disminución de algunas especies se relaciona con la drástica reducción de hábitats originales tales como bosques y humedales, tres especies propias de hábitats abiertos también se han visto afectadas. Se identifican como probables factores la expansión de la agricultura intensiva (a expensas de las áreas previamente dedicadas a la ganadería), la contaminación por agroquímicos, los conflictos con los intereses humanos y ciertos factores como el tamaño corporal, la proximidad del valle medio del Cauca al límite superior de distribución altitudinal de estas especies y el relativo aislamiento del valle con respecto de la región del Caribe y de las sabanas al oriente de los Andes. Se relieva la necesidad de establecer programas de monitoreo de las faunas de vertebrados, incluídas las especies consideradas como comunes en hábitats abiertos y perturbados.

\section{Introduction}

Certain aspects of the ecology and conservation of Neotropical rainforest raptors have received some attention, and it has been widely recognized that large-scale tropical deforestation will result in the extinction of many species (e.g. Newton and Chancellor 1985, Thiollay 1989, Whitacre et al. 1991). Raptors of open habitats such as savannas and shrublands, in contrast, have been largely ignored, and there is no great concern about the long-term viability of their populations. Most species of the latter group have wide geographic ranges and 
are considered common. Furthermore, as they could supposedly benefit from deforestation, they are deemed free from at least the associated apparent threats (Cade 1982, Hilty 1985. Hilty and Brown 1986). However, large-scale transformation of heterogeneous landscapes for intensive agriculture can have negative effects even on common species.

In the middle Cauca Valley, south-western Colombia, historical information suggests that several raptors, including species of open habitats, have declined in association with such landscape changes. In this paper we report on the status there of resident diurnal raptors and discuss the probable causes for the decline of some species.

\section{Study area and methods}

The Cauca River runs in a south-north direction between the Western and Central Andean ranges in Colombia. In its middle portion, between the localities of Santander de Quilichao $\left(3^{\circ} \mathrm{O} 1^{\prime} \mathrm{N}\right)$ and La Virginia $\left(5^{\circ} 05^{\prime} \mathrm{N}\right)$, the river forms a flat, alluvial valley $220 \mathrm{~km}$ long and $10-20 \mathrm{~km}$ wide, with an area of about 420,000 ha, between 800 and 1,100 m elevation (CVC 1990). In this paper "Cauca Valley" refers to the geographical entity as described above, and not to the political subdivision of the same name.

A dominant feature of the valley's physiognomy is the meandering river, which seasonally floods low-lying terrain and maintains oxbow lakes and ephemeral wetlands. According to anecdotal sources and antique engravings, closed-canopy floodplain forests were extensive. However, because of the high fertility of the valley's soil, native vegetation has been subjected to intense modification, initially for cattle-ranching, and later for intensive agriculture (e.g. sorghum, soybean, sugarcane and cotton). These changes have brought about a deterioration of natural habitats and their associated fauna (Alvarez-López et al. 1991). From 1957 to 1986 , forest cover was reduced from 25,320 to 8,668 ha, a loss of $66 \%$ (CVC 1990). As for wetlands, which were originally a dominant feature of the Cauca Valley landscape, the reduction in area for the same period was $72 \%$, from 10,049 to 2,795 ha (Restrepo and Naranjo 1987). No data are available for these trends prior to 1957 , but although landscape modification in the Cauca Valley is a centuries-old process, we can assume that the rate of transformation has accelerated in recent decades.

We have relied on published records, collection specimens, and our personal experience to assemble a historical list of species and determine which are still present. We have included only those species for which there is supporting evidence of their status as residents in the Cauca Valley, and therefore they constitute a minimal list. We follow the taxonomy and nomenclature of Hilty and Brown (1986).

\section{Results}

Table 1 shows all species for which there is historical documentation of former or current residence in the Cauca Valley, including the Pearl Kite Gampsonyx suainsonii, which has recently invaded this region. Other species (Bicoloured Hawk Accipiter bicolor, Orange-breasted Falcon Falco deiroleucus and Laughing 
Table 1. Body size (total length, $\mathrm{cm}$ ), habitat, altitudinal range $(\mathrm{m})$, and conservation status of resident diurnal raptors of the Cauca Valley.

\begin{tabular}{|c|c|c|c|c|}
\hline Species & Size & Habitat & Range & Status $^{a}$ \\
\hline American Kestrel Falco sparerias & $23-38$ & Savannas & $0-3,200$ & STA \\
\hline Aplomado Falcon Falco fentoralis & $36-43$ & Savannas & $0-1,000$ & UNK \\
\hline Bat Falcon Faloo rufigularis & $23-30$ & $\begin{array}{l}\text { Forest, } \\
\text { woodland }\end{array}$ & $0-1,600$ & EXT \\
\hline Black-shouldered Kite Elamus cartuleus & $38-43$ & $\begin{array}{l}\text { Savannas, } \\
\text { wetlands }\end{array}$ & $0-1,000$ & UNK \\
\hline Crested Caracara Polyborus plancus & $51-61$ & Savannas & $0-3,000$ & STA? \\
\hline Great Black-hawk Buteogallus urubitinga & $56-64$ & Forest & $0-1,000$ & EXT \\
\hline Harris's Hawk Parabuteo unicinctus & $4^{8-56}$ & $\begin{array}{l}\text { Savannas, } \\
\text { scrubland }\end{array}$ & $0-1,500$ & EXT \\
\hline Hook-billed Kite Chondrohierax uncinatus & $41-46$ & Forest & $0-1,000$ & EXT \\
\hline Long-winged Harrier Circus buffoni & $46-61$ & Wetlands & $0-1,000$ & EXT \\
\hline Pearl Kite Gampsonyx saninsonii & 20 & Savannas & $0-1,000$ & EXP \\
\hline Roadside Hawk Buteo magnirostris & $33-38$ & $\begin{array}{l}\text { Savannas, } \\
\text { woodland }\end{array}$ & $0-2,500$ & STA \\
\hline Savanna Hawk Heterospizins meridionalis & $46-61$ & $\begin{array}{l}\text { Savannas, } \\
\text { wetlands }\end{array}$ & $0-1,000$ & EXT \\
\hline Snail Kite Rostrhamms socinbilis & $41-46$ & Wetlands & $0-1,000$ & END \\
\hline White-tailed Hawk Buteo abicaudatus & $51-61$ & $\begin{array}{l}\text { Savannas, } \\
\text { scrubland }\end{array}$ & $0-1,800$ & END \\
\hline Yellow-headed Caracara Miliago dimachima & $41-46$ & Savannas & $0-2,500$ & STA \\
\hline
\end{tabular}

'EXT, possibly extinct; UNK, unknown, not enough information; END, endangered; STA, stable populations; EXP, expanding

Data on size, habitat and range are from Hilty and Brown (1986).

Falcon Herpetotheres cachinnans) are excluded because the paucity of records suggests that they were accidentals. Hilty and Brown (1986) mention that the Crane Hawk Geranospiza caerulescens was formerly present in the valley, but we have found no other evidence and therefore excluded it as well. For analysis we have partitioned the species among three main habitat types: forests, wetlands, and open country (i.e. extensive pastures with scattered trees, and plantations).

At least three species of forest raptor occurred in the Cauca Valley. As forests are now virtually non-existent, it is likely that all three are regionally extinct. Lehmann (1957) reported collecting several specimens of Great Black-hawk Buteogallus urubitinga between 1935 and 1940, at the localities of La Paila and Caicedonia, where extensive forests existed. These forests were replaced by sugarcane, and he considered this hawk regionally extinct by 1957. The Bat Falcon Falco rufigularis was reportedly common in shaded coffee and cocoa groves, where it fed on bats and swallows (Lehmann 1959). These forest-like plantations have largely disappeared from the valley and the Bat Falcon has not been recorded since (pers. obs.). The occurrence of Hook-billed Kite Chondrohierax uncinatus in the valley and on its adjacent slopes is supported by specimens reported in Chapman (1917) and at the collection of the Instituto Vallecaucano de Investigaciones Científicas (INCIVA) in Cali. The only records of this species in the last 15 years (Orejuela et al. 1979, Corredor 1989, H.A.L. pers. obs.), are from small forest remnants (50-60o ha) at mid-elevations $(1,100-$ $1,600 \mathrm{~m}$ ) on both slopes of the Cauca Valley. 
We have records for only two species of wetland raptor in the valley. Long-winged Harrier Circus buffoni was apparently always rare. Two females were collected in 1946 and 1947 at the southern end of the valley (von Sneidern 1954), but it has not been reported since. The Snail Kite Rostrhamus sociabilis still persists in the valley and is regularly recorded at Laguna de Sonso (c.1,00o ha) and at small ponds in farms south of Cali. Reproduction by a pair of Snail Kites was recorded at a 6 ha pond near Jamundí in 1988, 1989 and 1990 (G.H.K. unpubl. data).

Ten species of open-country raptor have historically been recorded in the Cauca Valley. Of these, we consider two species, Harris's Hawk Parabuteo unicinctus and Savanna Hawk Heterospizias meridionalis to be regionally extinct. Harris's Hawk was apparently common, as there are several nesting records from the 1950s (Lehmann 1957, 1960). Savanna Hawks were collected by Lehmann up to 1965 (specimens in INCIVA), and according to him this species was abundant (Lehmann 1957). Both raptors were found in ranchland and marshes in the southern part of the valley (Lehmann 1957). The most recent sighting of Savanna Hawk is from 1980 (H.A.L. pers. obs.) near Jamundí. Although we frequently do fieldwork in this region in habitats where both species could be found, we have failed to obtain further records.

White-tailed Hawk Buteo albicaudatus was also reportedly common, especially in semi-arid habitats in the foothills of the western Andes (Lehmann 1957). Nests were recorded near Yumbo (Lehmann 1957), and Bosque Yotoco (1973, in Hilty and Brown 1986). Although we frequently drive through these regions, we have not recorded this species. Naranjo (1992) recorded White-tailed Hawk as "rare" in 1982 near the northern end of the valley. Although its present population status is unknown, we consider it to be highly endangered, if not already regionally extinct.

For two species, Black-shouldered Kite Elanus caeruleus and Aplomado Falcon Falco femoralis, there is insufficient information to support any assessment. Lehmann (1960) reported Black-shouldered Kite as common in the Cauca Valley and in the Popayán Plateau. There are several records of individuals of this species between 1984 and 1994 (H.A.L. pers. obs.), but there is no quantitative information to establish population trends. Similarly, we have sighted Aplomado Falcon on several occasions between 1985 and 1991, but there is no historical information on its abundance and we cannot assess its current trends.

American Kestrel Falco sparverius, Yellow-headed Caracara Milvago chimachima and Roadside Hawk Buteo magnirostris are common in a variety of habitats in rural and suburban areas, and are seemingly not under immediate threat, although population censuses are lacking. The Crested Caracara Polyborus plancus is not common and there is no historical information on its abundance to determine population trends, but it remains regularly recorded in appropriate habitats.

The Pearl Kite Gampsonyx swainsonii is presently expanding its range south, probably along the Cauca Valley from the Caribbean lowlands. It was first reported at the northern end of the valley near Cartago in 1981 (Naranjo and Rodríguez 1981), and by 1993 it had been repeatedly sighted in both rural and urban settings as far south as Popayán (H.A.L. pers. obs.). 


\section{Discussion}

Historical records indicate that populations of at least 14 species of resident diurnal raptor occurred in the Cauca Valley, and a fifteenth species is now colonizing the region. Six of these species are probably extinct, and at least two more are highly endangered. Habitat modification is probably the primary cause of these population declines. Forest habitats have been virtually extirpated from the valley and its immediate foothills (CVC 1990). Wetlands are following a similar course. Laguna de Sonso is the only substantially large remnant of a formerly extensive wetland system (Restrepo and Naranjo 1987). It is not surprising, therefore, that species such as Hook-billed Kite, Great Black-hawk, Bat Falcon and Long-winged Harrier are regionally extinct.

Although information on historical abundance and present population status of Snail Kite in the Cauca Valley is lacking, we can assume that the species has declined with wetland reduction. However, Snail Kites still persist and breed in habitats such as small reservoirs and irrigation ditches. Small wetlands constitute critical habitat for Snail Kite populations during drought years in Florida, U.S.A. (Takekawa and Beissinger 1989). Although small wetlands could support a population for a few years, these habitats are very vulnerable because of their size and lack of protection. Therefore, long-term persistence of the Snail Kite in the Cauca Valley is far from guaranteed.

Large-scale modification of the valley's original habitats explains the extinction of only some species. Savanna Hawk, Harris's Hawk and White-tailed Hawk occupy open habitats such as grasslands with scattered trees and shrublands (Lehmann 1957, 1960, Hilty and Brown 1986). These species, however, have also disappeared. The Cauca Valley raptor fauna contained many species in common with other open grassy and shrubland habitats in Colombia, Venezuela, Argentina and Paraguay (Barreto 1981, Mader, 1981, Capurro and Bucher 1988, Hayes and Areco de Medina 1988). These species have large geographical ranges and occupy a variety of open habitats. Therefore, they should have low vulnerability (Kattan 1992) and would be expected to persist in non-forest habitats created for cattle-ranching. These habitats are very dynamic, and at least to some extent are heterogeneous and retain some complexity. However, during recent decades land use in the Cauca Valley has evolved toward extreme landscape homogenization, through urbanization and energy-intensive agriculture.

Thus while the area dedicated to crops such as soybean, sorghum, corn, and cotton fluctuated in the period 1990-1993, covering a total of about 100,000 ha mostly in the northern half of the valley, the area under sugarcane increased by $20 \%$ from 159,213 to 190,000 ha, and currently covers $45.2 \%$ of the valley's surface area (Anon. 1993). A large proportion of this increase has occurred in the southern portion of the valley, where lower fertility and higher rainfall have traditionally made cattle-ranching and rice cultivation the preferred land use (pers. obs.).

In contrast to cattle-ranching, intensive agriculture in the Cauca Valley, in particular sugarcane cultivation, features soil-levelling and extirpation of any other vegetation, including shade trees, hedges, and remnant riverine habitats, over expanses of hundreds of hectares. Thus a rather diverse landscape has 
been transformed into featureless monocultures that exclude raptors as well as many other species of bird. In addition, the associated load of agrochemical contaminants could have played a role in the extinction of several species of raptor. Population declines and eggshell thinning of White-tailed Hawk and Aplomado Falcon in relation to pesticide use has been documented elsewhere (Morrison 1978, Cade 1982).

The problem is not, however, restricted to the recent expansion of intensive agriculture, as declines in populations of several species (e.g. Great Black-hawk and Long-winged Harrier) can be traced to earlier times, when the Cauca Valley landscape was still relatively heterogeneous. In addition to the direct effects of landscape modification, some other factors might act to determine the high vulnerability of raptors in the area. With the exception of the Bat Falcon, all the extinct or endangered species are large (Table 1) and probably require large home ranges. The situation is particularly critical for forest species, as the surviving forest habitat in the Cauca Valley consists of fragments not larger than 10-12 ha. Non-endangered species, in contrast, are rather small and have opportunistic habits. American Kestrel, for example, defends small territories, has a catholic diet, and shows little habitat specificity (Murcia and Kattan 1984, Thiollay 1984, Balgooyen 1989). The only two large raptors that persist are the Yellow-headed and Crested Caracaras, both of which have diverse diets that include carrion and plant material.

Another factor that may have determined the high vulnerability of the Cauca Valley raptor fauna is geographical. Most of the extinct or endangered species are most abundant in the Caribbean lowlands and in the savannas east of the Andes (Hilty and Brown 1986). In the Cauca Valley ( $1,000 \mathrm{~m}$ elevation) they are close to the limit of their altitudinal distribution (Table 1), a factor that correlates with extinction probability (Kattan et al. 1994). Moreover, populations in this region are probably isolated, as the only connection with similar habitats is through a narrow valley in the foothills of the northern end of the Andes. This stretch of the lower Cauca Valley, covered by rainforest until recently (Espinal and Montenegro 1963), probably acted as a barrier to the dispersal of open-habitat raptors of the drier Caribbean lowlands. Therefore, population densities of some raptors in the Cauca Valley were probably always relatively low. Small raptors like the Pearl Kite have readily dispersed south to the middle Cauca Valley, taking advantage of the recent clearing of the lower valley's rainforest (Naranjo and Rodríguez 1981). Whether larger raptors will follow the same route and "rescue" the Cauca Valley populations (Brown and Kodric-Brown 1977) remains to be seen.

Conflict with other human interests should also be considered as a potential cause for the decrease of several raptors. In particular, large raptors are more prone to be considered harmful to farm animals, and have traditionally been shot on sight by farmers (Lehmann 1960), with no consideration of their real food habits. In Chile, for example, hunting of Harris's Hawk is allowed because it is popularly believed to be a raider of chicken roosts. A quantitative study, however, showed that chickens were not represented in the hawk's diet, although available (Jaksic and Jiménez 1986).

A variety of causes for the decrease of raptor populations has thus been preliminarily identified. Because of the paucity of information we shall probably 
never know what actually happened to reduce the populations of these raptors. The existence of historical records, in particular those of the late ornithologist F. C. Lehmann, who had a special interest in raptors, has allowed us to document changes in the Cauca Valley's bird fauna (see also Kattan et al. 1994). Prevention of further population declines and knowledge of its causes depends on the availability of information, which can only be obtained by establishing monitoring programmes. As is becoming increasingly clear, these programmes should include species that may be perceived as common (e.g. Dodd and Franz 1993), as their survival is far from certain.

\section{Acknowledgements}

We would like to thank the Instituto Vallecaucano de Investigaciones Cientificas for allowing access to their collections and to Dr Lehmann's records. We are also indebted to Natalia Gómez of the Centro de Datos para la Conservación, Corporación Autónoma Regional del Cauca (CVC), for her help in obtaining information. Craig Farquhar made suggestions that improved a previous version of this paper.

\section{References}

Alvarez-López, H., Kattan, G. and Giraldo, M. (1991) Estado del conocimiento y la conservación de la avifauna del Departamento del Valle del Cauca. Pp. 335-354 in Memorias del Primer Simposio Nacional de Fanna del Valle del Cauca. Cali, Colombia: Instituto Vallecaucano de Investigaciones Científicas.

Anonymous (1993) Balance agrícola regional 1993. SAG Información y Opinión Agropecuaria Nacional 11(10): 5-6.

Balgooven, T. G. (1989) Natural history of the American Kestrel in Venezuela. J. Raptor Res. 23: 85-93.

Barreto, M. (1981) Aves en El Porvenir, Meta, Colombia. Cespedesia 10: 149-163.

Brown, J. H. and Kodric-Brown, A. (1977) Turnover rates in insular biogeography: effect of immigration on extinction. Ecology 58: $445-449$.

Cade, T. J. (1982) The falcons of the world. Ithaca, N.Y.: Cornell University Press.

Capurro, H. A. and Bucher, E. H. (1988) Lista comentada de las aves del bosque chaqueño de Joaquín V. González, Salta, Argentina. Hornero 13: 39-46.

Chapman, F. M. (1917) The distribution of bird life in Colombia. Bull. Amer. Mus. Nat. Hist. 36: $1-729$.

Corredor, G. (1989) Estudio comparativo entre la avifauna de un bosque natural y un cafetal tradicional en el Quindío. Cali, Colombia: Trabajo de Grado, Universidad del Valle.

CVC (1990) Comparación de cobertura de bosques y humedales entre 1957 y 1986 con delimitación de las comunidades naturales críticas en el Valle Geográfico del Río Cauca.

Cali, Colombia: Informe CVC No. 90-7.

Dodd, C. K. and Franz, R. (1993) The need for status information on common herpetofaunal species. Herp, Reci, 24: 47-50.

Espinal, L. S. and Montenegro, E. (1963) Formaciones vegetales de Colombia: memoria explicatiza sobre el mapa écologico de Colombia. Bogotá, Colombia: Canal Ramírez (Instituto Geográfico Agustí Codazzi).

Hayes, F. E. and Areco de Medina, F. E. (1988) Notes on the ecology of the avifauna of Choré, Department of San Pedro, Paraguay. Hornero 13: 59-70. 
Hilty, S. L. (1985) Distributional changes in the Colombian avifauna: a preliminary blue list. Pp.1000-1012 in P. A. Buckley, M. S. Foster, E. S. Morton, R. S. Ridgely and F. G. Buckley, eds. Neotropical ornithology. Washington, D.C.: American Ornithologists' Union (Orn. Monogr. 36).

Hilty, S. L. and Brown, W. L. (1986) A guide to the birds of Colombia. Princeton, New Jersey: Princeton University Press.

Jaksic, F. M. and Jiménez, J. E. (1986) The conservation status of raptors in Chile. Birds of Prey Bull. 3: 95-104.

Kattan, G. H. (1992) Rarity and vulnerability: the birds of the Cordillera Central of Colombia. Conserv. Biol. 6: 64-70.

Kattan, G. H., Alvarez-López, H. and Giraldo, M. (1994) Forest fragmentation and bird extinctions: San Antonio eighty years later. Conserv. Biol. 8: 138-146.

Lehmann, F. C. (1957) Contribuciones al estudio de la fauna de Colombia XII. Novedades Colombianas 1: 101-156.

Lehmann, F. C. (1959) Notas generales. Novedades Colombianas 1: 223-226.

Lehmann, F. C. (1960) Contribuciones al estudio de la fauna de Colombia XV. Novedades Colombianas 1: $256-276$.

Mader, W. J. (1981) Notes on nesting raptors in the llanos of Venezuela. Condor 83: $48-51$.

Morrison, M. L. (1978) Breeding characteristics, eggshell thinning, and population trends of White-tailed Hawks in Texas. Bull. Texas Orn. Soc. 11: 35-40.

Murcia, C. and Kattan, G. (1984) Notas sobre los hábitos alimenticios del Halcón Común, Falco sparverius. Actualidades Biológicas 13: 48-50.

Naranjo, L. G. (1992) Estructura de la avifauna en un área ganadera en el Valle del Cauca, Colombia. Caldasia 17: 55-66.

Naranjo, L. G. and Rodríguez, F. (1981) Sobre la presencia de Sarkidiomis melanotos y Gampsony $x$ swainsonii (Aves: Anatidae, Acciptridae) en el Valle del Cauca. Cespedesin 10: 213-221.

Newton, I. and Chancellor, R. D., eds. (1985) Conservation studies on raptors. Cambridge, U.K.: International Council for Bird Preservation (Techn. Publ. 5).

Orejuela, J. E., Raitt, R. J. and Alvarez-López, H. (1979) Relaciones ecológicas de las aves en la Reserva Forestal de Yotoco, Valle del Cauca. Cespedesia 8: 7-28.

Restrepo, C. and Naranjo, L. G. (1987) Recuento histórico de la disminución de humedales y la desaparición de aves acuáticas en el valle geográfico del río Cauca, Colombia. Pp.43-45 in H. Alvarez-López, G. Kattan and C. Murcia, eds. Memorias III Congreso de Ornitología Neotropical. Cali, Colombia.

von Sneidern, K. (1954) Notas sobre algunas aves del Museo de Historia Natural de la Universidad del Cauca, Popayán, Colombia. Novedades Colombianas 1: 3-13.

Takekawa, J. E. and Beissinger, S. R. (1989) Cyclic drought, dispersal, and the conservation of the Snail Kite in Florida: lessons in critical habitat. Conserv. Biol. 3: 302-311.

Thiollay, J. M. (1984) Stratégie d'exploitation de milieux désertiques chez la Crécerelle Américaine, Falco sparverius L. Acta Oecologica/Oecologia Generalis 5: 261-283.

Thiollay, J. M. (1989) Area requirements for the conservation of rain forest raptors and game birds in French Guiana. Conserv, Biol. 3: 128-137.

Whitacre, D. F., Burnham, W. A. and Jenny, J. P., eds. (1991) Maya Project: use of raptors and other fauna as environmental indicators for design and management of protected areas and for building local capacity for conservation in Latin America. Boise, Idaho: The Peregrine Fund, Inc. World Center for Birds of Prey (Progress Report iv).

HUMBERTO ALVAREZ-LÓPEZ

Departamento de Biología, Universidad del Valle, Apartado 25360, Cali, Colombia.

GUSTAVO H. KATTAN

Wildlife Conservation Society, Apartado 25527, Cali, Colombia. 